one of a series of specialist groups which are being formed among members of Aslib to consider the recording and dissemination of literature and technical information in special fields. The following committee was elected to control the work of the Group : Mr. R. G. Thorne, Royal Aircraft Establishment (chairman); Mr. C. W. Cleverdon, College of Aeronautics (secretary); Mr. A. H. Holloway, Technical Information Bureau, Ministry of Supply; Mr. T. G. Dickson, Rolls Royce, Ltd.; Mr. J. A. Kirk, Short Bros. and Harland, Ltd. ; Mr. A. R. Cameron, A. V. Roe and Co., Ltd. ; Mr. P. S. Walkins, British European Airways; Mr. F. H. Smith, Koyal Aeronautical Society; Mrs. M. Neal, Engineering. 'Working parties' were set up to consider the following subjects : abstracting services; classification of aerodynamic data; union catalogue of the holdings of aeronautical libraries. Suggestions for consideration by the Group should be sent to the Secretary, Mr. C. W. Cleverdon, at the College of Aeronautics, Cranfield, Beds, or to members of the Committee. It is intended to hold an open meeting next spring to report on the work of the Group.

\section{Meeting of Phycologists at Bangor}

A Group of twenty-eight phycologists, the majority of them students of marine alge, met at Bangor, North Wales, during September 13-20. During the week, excursions were made to the shores at Treaddur Bay, Rhoscolyn, Rhosneigr, Penmon Point and the Menai Straits, and one day was devoted to dredging in the Menai Straits, thanks to the kind co-operation of Dr. Crisp and the staff of the Marine Biological Station. These field meetings gave those attending the opportunity of comparing not only the composition of the flora with that of shores more intimately known to them but also the times of occurrence of reproduction of various common seaweeds. In addition, some lesser-known alg were found and taxonomic difficulties discussed. Prof. P. W. Richards generously provided laboratory facilities, which were used to the full both for the examination of the freshly collected material and also for a series of valuable demonstrations, illustrating the very diverse types of research in progress. Although some of these had bearings on more than one type of problem, these exhibits could be classified broadly as ecological (Blackler, Moss), taxonomical (Burrows and Lodge, Parke, Powell), morphological (Martin, Richards, Mullahy, Dixon), and another group dealt with methods of culture and results obtained by this type of investigation (Parke, Knight Jones, Droop, Drew).

This informal group of phycologists has decided to hold further meetings, thereby hoping to encourage critical and experimental work on marine algæ, and anyone interested is asked to communicate with either Dr. K. M. Drew, Department of Cryptogamic Botany, University of Manchester, or Mr. H. T. Powell, of the Marine Biological Station, Keppel Pier, Millport. A duplicated news-sheet, containing notes of use to marine phycologists, will be available early in 1952, and the preparation of a check-list of the marine flora of the British Isles has been planned. A meeting of about a week's duration has been arranged provisionally to be held at Plymouth during July 1952 when, in addition to field meetings, consideration will be given to a special topic (possibly techniques used in the preparation of material for cytology and in the culture of algæ) and also to the taxonomy of a single family, probably the Doles. seriaceæ. Inquiries about the possibility of a one-day meeting in London, during the first week in January 1952 , are also being made.

\section{Mythical Dwarf People in Polynesian Legend}

THE existence of 'little people' is a belief that is of world-wide, though sporadic, occurrence. For the most part, they are dwarfish, more-or-less benevolent, hard-working in spite of their small stature, nocturnal and dwelling underground or in woods or forests. Such being their attributes, they are very difficult to pin down, as their habits make observation extremely difficult, and accounts of them vary with almost every supposed observer. In the Hawaiian Islands these nocturnal pygmies are known as 'Menehune', and Katherine Luomala, whose researches into Po'ynesian folk-lore are well known, gives an extensive and fascinating investigation of this subject in a booklet entitled "The Menehune of Polynesia and other Mythical Little People of Oceania" (Bernice P. Bishop Museum, Honolulu; Bull. 203; pp. 95; 1951). Her account of these tiny folk is gathered from many sources and includes their physical and cultural characteristics, their housing and social structure, their relations with other little peoples and their possible origin. All this gives them such a corporal existence that it is quite difficult to believe that they are mythical. They originate, apparently, from the old semi-slave common class of people who did all the hard work and were presumably stunted by toil and privation. The buildings they erected soemed worthy of a tradition, and so by the usual process of exaggerating the size of the subjects of the tradition both down and up (the clever little man and the stupid giant) these Menehune became smaller and smaller as time went on in order that their works might be more glorified. Other Polynesian islands also have their legends of Menehune or similar little peoples, and an account is given of the various myths connected with them.

\section{Tarnish and Corrosion of Silver and Bronze}

Two papers in the Museums Journal discuss the corrosion of silver and bronze respectively, problems which are of interest to a circle far wider than that of museum curators. The article on silver, by Dr. Bengt Thordeman and Mr. Gillis Olson, of the National Historical Museum, Stockholm, is contained in the February issue of the Journal and is a summary of their recent investigations of the well-known black or brownish tarnish of this metal. . The present solution of the problem is to cover the cleaned silver with a film of nitrocellulose lacquer. The result of this treatment is not completely successful, for in some cases the protecting film gradually cracks and eventually gives rise to a network of unattractive black lines. The authors now consider that the rapidly developing plasties industry has provided a new method of approach, and a commercial lacquer of the acrylate type called 'Acryloid B7', produced by the Resinous Products and Chemical Co., Philadelphia, has been used. The silver is first cleaned by washing in dilute ammonia and removing the resulting film of black sulphide by contact with zine or alum. inium in a weak solution of sodium carbonate. After washing with distilled water and drying at $50-60^{\circ} \mathrm{C}$., the still warm objects are dipped in an approximately 8 per cent solution of the lacquer. After excess of fluid has been drained off, the objects are baked at a temperature of $60-70^{\circ} \mathrm{C}$. The other article, in the January issue of the Journal, is by Mr. J. F. S. 